\title{
ФОРМУВАННЯ МІЖКУ ЯЬТУРНОЇ КОМПЕТЕНТНОСТІ У ПРОЦЕСІ ПРАКТИЧНОЇ ПІДГОТОВКИ МАЙБУТНІХ ФАХІВЦІВ БОЙОВОГО ТА ОПЕРАТИВНОГО ЗАБЕЗПЕЧЕННЯ
}

У статті проаналізовано ефективність формування міжкультурної компетентності у процесі практичної підготовки майбутніх фахівців бойового та оперативного забезпечення.

У період навчання майбутніх фахівців бойового та оперативного забезпечення офіцери оволодівають навичками, вміннями, методами та формами організацї професійної діяльності, а саме: вправляються у виконанні службових обов'язків у військових частинах, закріплюють теоретичні знання, розвивають навички облаштування укриття з використанням маскувальних властивостей місиевості, влаштування загородження, ведення бою тощь. На командно-итабних, тактичних навчаннях курсанти відпрацьвовують методи ведення операції або бою на тлі спеціально створеної військово-політичної, стратегічної, оперативної та бойової обстановки.

Звернуто увагу, що у процесі проходження практики майбутні фахівці бойового та оперативного забезпечення повинні розвивати мовні знання, такі як: полікультурні знання, знання про військово-професійні цінності, правила вербальної та невербальної комунікативної поведінки військовослужбовиіів. Метою їх навчання є отримання знань про стилі спілкування американських, англійських військовослужбовцців та використання комунікативних стратегій для досягнення мети, вхіння вести діалог з представниками інших культур. Військовослужбовці закріплюють навички толерантної комунікативної поведінки, здатність контролювати свої дї під час спікування, зокрема вміння долати страх, етнічні та культурні стереотипи

Зроблено висновки, ще під час проходження курсантами навчальної $і$ військової практики в умовах, наближених до реальних, з метою формування міжкультурної компетентності виявили проблемно-пошукові методи навчання, а саме кейс метод та навчально-рольова гра. Застосування кейс методу сприяе створенню умов для формування навичок й умінь, що є вагомими складовими міжкультурної компетентності. Навчальнорольова гра передбачае моделювання ситуациій професійно орієнтованого спілкування й має на меті навчання майбутніх фахівціів бойового та оперативного забезпечення прийняттю рімень.

Ключові слова: міжкультурна компетентність, комунікативна компетентність, майбутні фахівці бойового та оперативного забезпечення, практична підготовка, військовопрофесійна підготовка.

Постановка проблеми. В сучасних умовах метою військових блоків є взаємопідтримка держав у процесі захисту їх територіальної цілісності, гуманітарних операцій у складі міжнародних організацій, а саме: НАТО, $\mathrm{EC,OOH,} \mathrm{вирішення}$ військових конфліктів, тому для військовослужбовців стає особливо важливою здатність до міжкультурної комунікації. Згідно 3 міжнародною програмою НАТО «Партнерство заради миру» та посилення співробітництва 3 державами-партнерами України, розвиток у майбутніх фахівців бойового та оперативного забезпечення міжкультурної компетентності набуває важливої ролі у їхній професійній діяльності. За допомогою міжкультурної компетентності майбутні військовослужбовці зможуть повноцінно

*(C) Аюбас A. A.

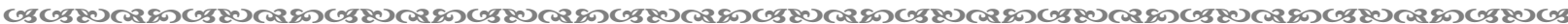
160 
виконувати свої професійні обов'язки під час міжнародних навчань та багатостороннього співробітництва із залученням представників НАТО [5].

Аналіз досліджень. Для випускників вищих військових навчальних закладів практична підготовка є необхідним елементом військово- професійної підготовки [10].

у праці «Педагогіка туризму» В. Федорченка, Н. Фоменка, М. Скрипника, Г. Цехмістрової практична підготовка інтерпретується як складова частина професійної освіти, що відображає методи і форми, зміст організації процесу та формування умінь і навичок. Цей процес спрямований на підвищення здатності військовослужбовців до спеціалізованої праці та розвиток кдючових компетентностей [7, с. 169]. Дидактична мета практичної підготовки курсантів полягае в овододінні вміннями, навичками, методами, формами та засобами організації майбутньої професійної діяльності [11, с. 318].

М. Дзіковська вважає, що практична підготовка допомагає закріпити уміння, знання та навички, які набуваються курсантами у процесі їхньої професійної підготовки [3, с. 85].

В. Шевчук та О. Сідельник зауважують, що практична підготовка формуе готовність до прийняття самостійних рішень, виходячи з певної ситуації [14, с. 191].

Мета статті - з'ясувати шляхи формування та набуття міжкультурної компетентності курсантами під час проходження практичних занять.

Виклад основного матеріалу. У дисертації А. Аюбас підкреслено, що практична підготовка, як і військово-професійна підготовка, допомагає сформувати у майбутніх фахівців бойового та оперативного забезпечення професійно значущі знання, уміння та навички, а також індивідуадьно-психологічні якості особистості [5].

У практичну підготовку входять такі компоненти: зміст, мета, форми, методи, організаційно-методичне забезпечення військово-професійної підготовки курсантів. Головні принципи реалізації практичної підготовки визначені у робочих навчальних програмах та робочих планах навчальних дисциплін [там само].

Під час проходження практики отримані теоретичні знання переходять у практичну площину. 3'являеться потреба в активній навчальній діяльності, що визначається моделлю майбутньої посади, яка реалізується у кваліфікаційних вимогах та допомагає удосконалити професійні навики та вміння [2, с. 15].

Головні завдання практичної підготовки військовослужбовців: частинах

- отримати уміння і навички під час виконання службових обов' язків у військових

- набути навички та уміння у формуванні ціннісних орієнтацій;

- погдибити та закріпити теоретичні знання, отримані під час навчання [5].

Модель особистості військового фахівця включає в себе такі елементи: настанова на професію, чіткість громадянських та професійних позицій, інтерес до військової служби, спеціальні та організаторські здібності, внутрішня цілісність особистості, iii настанов і справ, відносин і реальної поведінки, уміння відстоювати свої переконання та добиватися реалізації поставлених цілей [6, с. 167].

Практична підготовка курсантів повинна визначати основні види професійної компетентності, позитивно мотивувати майбутніх військовослужбовців до подальшої військово-професійної діяльності [5].

Під час проходження практичної підготовки курсанти опановують комунікативну, міжкультурну й управлінську компетентності [там само].

Управлінська компетентність формується під час діалогічних взаємин викладача і курсанта та продовжується у процесі проходження ними практичної підготовки. В умовах навчальних ситуацій курсанти відпрацьовують навчально-бойові завдання, здобуваючи при цьому навички та уміння діяти у критичних ситуаціях, розвивають самостійність мислення, формують індивідуальний стиль управдіння. Це проявляється 
уситуаціях із використанням сучасних зразків озброєння військової, а також електронно-обчислювальної техніки [3; 5].

Комунікативна компетентність допомагає курсантам морально та психологічно адаптуватися, а також сприяє успішній комунікативній взаємодії. Емоційне сприйняття бійцем інших військовослужбовців має зворотну силу впливу на інтелектуальну та вольову сферу особистості, а також військового колективу. Це є основа формування відповідного самопочуття воїнів. Сприятливе комунікативне середовище забезпечує злагоджені дії під час несення служби [1, с. 181; 5].

Практична підготовки майбутніх військовослужбовців поділяеться на: первинну військово-професійну підготовку, навчальну, військову, ремонтну практики курсантів та військове стажування [10].

Розглянемо особливості навчальної та військової практики майбутніх військовослужбовців. Виконуючи практичні дії на польовій навчально-матеріальній базі Міжнародного центру миротворчості та безпеки, курсанти мають можливість ознайомитися зі зразками озброєння, автомобільною технікою, броньованими засобами пересування, а також засобами зв'язку [5].

Участь у діях у складі миротворчих місій підроздіяів Збройних Сил України, передбачає підготовку відповідного рівня сумісності зі збройними силами держав членів НАТО та ЕС [там само].

Командно-штабні навчання визначаються як форма спільного навчання командирів і штабів, узгоджена спільна діяльність 3 управління підпорядкованими органами та підрозділами. Метою даних навчань є: відпрацювання бойових дій, покращення управлінської діяльності та вирішення завдань щодо найбільш важдивих етапів розвитку військових дій. Командно-штабні навчання починаються в місцях постійної дислокації або у вихідних районах. На цих навчаннях майбутні фахівці бойового та оперативного забезпечення відпрацьовують підготовку та проводять операції на тлі спеціально створеної стратегічної, військово-політичної, оперативної або бойової обстановки. Згадані навчання поділяються:

- за масштабами - на стратегічні, оперативні, оперативно-тактичні й тактичні, оперативно-стратегічні;

- 3 організації управління - із засобами зв'язку і без них;

- за складом - залучені сили і засоби з позначеними військами і без них;

- за характером поставлених цілей - дослідницькі, дослідні та спеціальні,звичайні, показні;

- за методами проведення - односторонні, двосторонні, одноступеневі та багатоступеневі [5].

В останні роки виділяється нова форма командно-штабних навчань-комп'ютерні навчання (CAX - Computer Assisted Exercise) [5; 9].

Курсанти залучаються до виконання поставлених керівництвом штабу оперативно-службових завдань у складі відповідних підрозділів під час виконання практичних занять [5].

Тактичні навчання - це основна форма польового вишколу частин та підрозділів, що е важливим засобом підвищення бойової готовності військ. Навчання можуть бути двосторонніми або односторонніми, але 3 обов'язковим позначенням ворога. На навчаннях більша частина часу відводиться бойовим діям [8, с. 26].

Підрозділи мають практично виконувати всі необхідні в сучасному бою роботи, а саме:

- обладнувати укриття для особового складу, озброєння й бойової техніки;

- здійснювати заходи щодо маскування і вдаштовувати загородження;

- здійснювати технічне обслуговування бойової техніки, автотранспорту та інші заходи відповідно до визначеної обстановки і фактичного стану підрозділів, а також здійснювати заходи 3 надання медичної допомоги [13, с. 34].

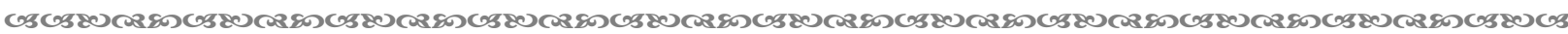
162 
Навчальні цілі даних навчань спрямовані на досягнення готовності до виконання військових завдань, відпрацювання питань щодо висування підрозділу, розгортання у бойовий порядок, ведення зустрічного бою, пересування підрозділу, відходу і виходу 3 бою. У ході навчань рішення щодо розіграшу бойових дій самостійно приймається командиром рівня взвод-рота-батальон. Курсанти набувають практичні навички ведення бою, комунікативної взаємодії, вдосконалюють свою військову майстерність в умовах, максимально наближених до реальних [5].

Міжнародні інтеграційні процеси військової співпраці, вимоги до рівня підготовки військовослужбовців зумовлюють необхідність овододіння ними міжкультурною компетентністю, а відтак - перехід від педагогічного традиціоналізму до нових методів та форм навчання, зорієнтованих на формування творчої, свідомої особистості, а також компетентного військового спеціаліста, який здатний до успішної міжкультурної комунікації [там само].

Основний ворог раціонального військового мистецтва та вмілого керування шаблонність дій командира, що призводить до втрати військовослужбовцем уміння проявляти оригінальність під час вирішення поставлених завдань та творчо мислити [2, с. 16].

Практична підготовка i військова професійна підготовка повинні надавати майбутньому військовому спеціалісту вміння та навички поєднувати в різних варіантах теоретичні завдання та наукові здобутки з вирішення питань, які виникають у реальній військовій професійній діяльності [5].

П. Сердюков вважав, що застосування науково обгрунтованих методів, засобів і прийомів у процесі навчання передбачає створення системи технічних, програмних, навчальних і методичних засобів, які сприятимуть ефективному розв'язанню професійних, навчальних та наукових завдань у процесі проходження практичних занять [12, с. 7]

Перехід до інноваційної освіти вкдючає реалізацію таких організаційнометодичних засад як:

- створення комп'ютерних (інформаційних систем його підтримки), комп'ютеризація освітнього процесу, оновлення нормативної та навчально-методичної документації;

- реалізація інтегрованих навчальних курсів зі загальнонаукової, загальновійськової та спеціальної підготовки в єдиний блок військово-професійної підготовки;

- введення нових навчальних спецкурсів у навчальні плани;

- розробка інтерактивних систем навчально-методичного забезпечення навчальних дисциплін;

- суттеве збільшення навчального часу для практичної складової професійної підготовки майбутніх фахівців бойового та оперативного забезпечення [5].

Активні та інтерактивні методи навчання вважаються найбільш ефективними серед інноваційних технологій навчання. Доцільність їх використання підтверджується швидким розвитком інформаційно-комунікаційних технологій [там само].

Проведення багатонаціональних навчань та тренувань передбачає досягнення ефективності спільних дій згідно сценарію навчань, тактичної обстановки бойового завдання. Міжнародні навчання проводяться в Україні з метою відпрацювання питання боєздатності підрозділів, готовності до виконання завдань бойового, иогістичного і гуманітарного характеру у випадку відбиття збройної агресії та під час операцій миротворчого і стабілізаційного характеру в складі коаліційних сил. Відбувається поглиблення тактичної та оперативно-тактичної сумісності української армії зі збройними силами країн-партнерів, країн НАТО на рівні штабів та підрозділів. Під час проходження таких міжнародних навчань відбувається інтенсивна професійна міжкультурна взаємодія військових. Оперативно-тактична здагодженість дій залежить

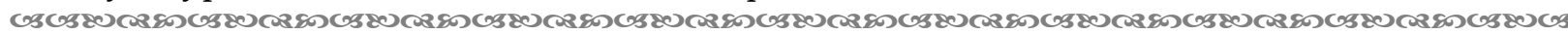


від вербального порозуміння, правильного вибору комунікативних стратегій спілкування, невербальної поведінки та толерантності [там само].

У процесі міжкультурної взаємодії можуть виникати непорозуміння, проявлятися етноцентричні установки, забобони, критична оцінка чужої культури. Вище перелічені чинники не сприятимуть ефективному виконанню завдань [5].

Розвиток відповідних знань, навичок та умінь у процесі проходження навчальної та військової практик сприятиме підвищенню рівня міжкультурної компетентності курсантів. До знань і умінь, які варто розвивати у процесі проходження практичної підготовки і які забезпечать майбутнім офіцерам ефективну міжкультурну комунікацію у процесі проходження практики, відносимо:

- мовні знання, полікультурні знання, знання про військово-професійні цінності, правила вербальної та невербальної комунікативної поведінки військовослужбовців, знання комунікативних стратегій, знання про стилі спілкування американських та англійських військовослужбовців,

- вміння вести діалог 3 представниками інших культур, аналізувати комунікативну ситуацію, відбирати й використовувати відповідні комунікативні стратегії для досягнення комунікативної мети, здатність контродювати свої дії під час спілкування, зокрема вміння долати страх, етнічні та культурні стереотипи,толерантну комунікативну поведінку [4].

Висновки. Під час проходження курсантами практичної підготовки в умовах, наближених до реальних, з метою розвитку та удосконалення у них міжкультурної компетентності, використання проблемно-пошукових методів, а саме: кейс метод та навчально-рольова гра виявились ефективними.

Для подальшого формування міжкультурної компетентності майбутніх військовослужбовців у процесі проходження практики кейси та навчально-рольові ігри пропонується подавати англійською мовою.

Проаналізувавши вище викладений матеріал, ми дійшли висновку, що у процесі проходження курсантами практичної підготовки, потрібно створювати належні умови для удосконалення міжкультурної компетентності майбутніх фахівців бойового та оперативного забезпечення.

Перспективи подальших наукових досліджень полягають у дослідженні шляхів розширення та вдосконалення практичних навичок міжкультурної компетентності майбутніх офіцерів.

\section{Список використаних джерел:}

1. Барабанщиков А.В. Актуальные проблемы педагогики и психологии высшей военной школы. Москва: ВПА, 1980. 277 с.

2. Брижатий Є. І. Військово-професійна підготовка майбутніх офіцерів: від готовності до професіоналізму. Вісник Націзонального університету оборони Украйни, 2014. № 6 (43). С. 13-17.

3. Дзіковська М. І. Організація практичної підготовки майбутніх фахівців природничих спеціальностей у коледжі. Молодий вчений, 2018. № 3 (55). С. 84-89.

4. Пюбас А. А. Сутність і структура міжкультурної компетентності майбутніх фахівців бойового та оперативного забезпечення. Педагогічний альманах. 2017. Вип. 35. С. 154-160

5. Любас А. А. Педагогічні умови формування міжкультурної компетентності майбутніх фахівців бойового та оперативного забезпечення: дис. ... д-ра філософії: 015 / Аьвів. нац. ун-т ім. Івана Франка. Аьвів, 2021. 316 с.

6. Монастирський В. М. Педагогічні умови військово-професійної підготовки майбутніх офіцерів Збройних Сил України та правоохоронних органів держави у військових навчальних підрозділах ЗВО. Вісник Черкаського університету. Серія: «Педагогічні науки, 2019. Вип. № 1. С. 165-170.

7. Педагогіка туризму / Федорченко В. К., Фоменко Н. А., Скрипник М. І., Цехмістрова Г. С. Київ.: Вид. дім «Слово». 2004. 296 с. 
8. Петренко В. М., Ляпа М. М., Житник В. Є. Повсякденна діяльність командира підрозділу: навч. посіб. Суми: Сумський державний університет. 2014. 450 с.

9. Політика. Право. Життя. URL: www.Pollawlife.com.ua/2015/04 blog-post.html

10. Про затвердження «Положення про особливості організації освітнього процесу у вищих військових навчальних закладах Міністерства оборони України та військових навчальних підрозділах вищих навчальних закладів України». Наказ Міністерства оборони Украӥни № 346 sid 22.07.2015. URL: zakon.rada.gov.ua/laws/show/z1126-15/print

11. Рацул А. Б., Довга Т. Я., Рацул А. В. Педагогіка: інформативний виклад: навч. посіб. 2-ге вид. перероб. і доп. Київ., 2015. 320 с.

12. Сердюков П. І. Теоретичні основи навчання іноземних мов у мовному вузі з використанням інформаційних технологій: автор. ... дис. д-ра пед. наук: 13.00.02 / Київський державний лінгвістичний університет. 1997. 32 с.

13. Тактическая подготовка: учебн.-метод. пособ. / ред. В.М.Чайка, В.Н.Дорошкин. Москва: Военное издательство, 1989. 176 с.

14. Шевчук Т. В., Сідельник О. К. Практична підготовка студентів вищих навчальних закладів як невід'ємна детермінанта формування їхніх професійних компетенцій. Науковий вісник НИТУ України. Серіл економічна, 2017. Вип. 27. № 2. С. 189-192.

\section{Reference:}

1. Barabanshchykov, A. V. (1980). Aktualnye problemy pedahohyky y psykholohyy vysshei voennoi shkoly [Current problems of pedagogy and psychology of higher military school]. Moskva: VPA [in Russian].

2. Bryzhatyi, Ye. I. (2014). Viiskovo-profesiina pidhotovka maibutnikh ofitseriv: vid hotovnosti do profesionalizmu [Military-professional training of future officers: from readiness to professionalism]. Visnyk Natsionalnoho universytetu oborony Ukrainy, 6 (43), 13-17. DOI: http://nbuv.gov.ua/UIRN/Vnaou 201464 [in Ukrainian].

3. Dzikovska, M. I. (2018). Orhanizatsiia praktychnoi pidhotovky maibutnikh fakhivtsiv pryrodnychykh spetsialnostei u koledzhi [Organization of practical training of future specialists of natural sciences at the college]. Molodyi vchenyi, 3 (55), 84-89. DOI: http://nbuv.gov.ua/UIRN/ molv 2018 3\%281\%29 22 [in Ukrainian].

4. Liubas, A. A. (2017). Sutnist i struktura mizhkulturnoi kompetentnosti maibutnikh fakhivtsiv boiovoho ta operatyvnoho zabezpechennia [The essence and structure of intercultural competence of future specialists of combat and operational support]. Pedahohichnyi almanakh, 35, 154-160. DOI: http://nbuv.gov.ua/UIRN/pedalm 20173525 [in Ukrainian].

5. Liubas, A. A. (2021). Pedahohichni umovy formuvannia mizhkulturnoi kompetentnosti maibutnikh fakhivtsiv boiovoho ta operatyvnoho zabezpechenniain [Pedagogical conditions for the formation of intercultural competence of future specialists of combat and operational support]. (Candidate's thesis). Ivan Franko National University of Lviv. Lviv [in Ukrainian].

6. Monastyrskyi, V. M. (2019). Pedahohichni umovy viiskovo-profesiinoi pidhotovky maibutnikh ofitseriv Zbroinykh Syl Ukrainy ta pravookhoronnykh orhaniv derzhavy $\mathrm{u}$ viiskovykh navchalnykh pidrozdilakh ZVO [Pedagogical conditions of military and professional training of future officers of the Armed Forces of Ukraine and law enforcement agencies of the state in military educational units of higher education establishments]. Visnyk Cherkaskoho universytetu. Seriia: «Pedahohichni nauky», 1, 165-170. DOI: http://ped-ejournal.cdu.edu.ua [in Ukrainian].

7. Fedorchenko, V. K., Fomenko, N. A., Skrypnyk, M. I., \& Tsekhmistrova, H. S. (2004). Pedahohika turyzmu [Pedagogy of tourism]. Kyiv [in Ukrainian].

8. Petrenko, V. M., Liapa, M. M., \& Zhytnyk, V. Ye. (2014). Povsiakdenna diialnist komandyra pidrozdilu [Daily activities of the unit's commander]. Sumy [in Ukrainian].

9. Polityka. Pravo. Zhyttia [Politics. Right. Life]. Retrieved from http://www.pollawlife.com.ua/ 2015/04/blog-post.html [in Ukrainian].

10. Order of the Ministry of Defense of Ukraine dated July 22, 2015 No. 346. Regulations on the peculiarities of the organization of the educational process in higher military educational institutions of the Ministry of Defense of Ukraine and military educational units of higher educational institutions of Ukraine. Retrieved from https://zakon.rada.gov.ua/laws/show/z112615/conv/print [in Ukrainian].

11. Ratsul, A. B., Dovha, T. Ya., \& Ratsul, A. V. (2015). Pedahohika: informatyvnyi vyklad [Pedagogy: informative presentation]. Kyiv [in Ukrainian].

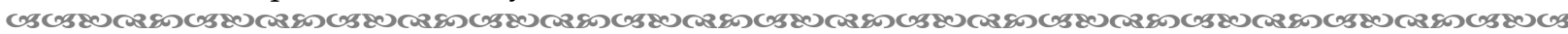
165 
12. Serdiukov, P. I. (1997). Teoretychni osnovy navchannia inozemnykh mov u movnomu vuzi $\mathrm{z}$ vykorystanniam informatsiinykh tekhnolohii [Theoretical bases of teaching foreign languages in a language university with the use of information technologies]. (Extended abstract of Doctor's thesis). Kyiv State Linguistic University. Kyiv [in Ukrainian].

13. Chaika, V. M., \& Doroshkin, V. N. (Ed.). (1989). Takticheskaia podgotovka [Tactical training]. Moskva: Voennoe izdatelstvo [in Russian].

14. Shevchuk, T. V., \& Sidelnyk, O. K. (2017). Praktychna pidhotovka studentiv vyshchykh navchalnykh zakladiv yak nevidiemna determinanta formuvannia yikhnikh profesiinykh kompetentsii [Practical training of students of higher educational institutions as an integral determinant of the formation of their professional competencies]. Naukovyi visnyk NLTU Ukrainy. Seriia ekonomichna, 2, 189-192. DOI: https://cyberleninka.ru/article/n/praktichnapidgotovka-studentiv-vischih-navchalnih-zakladiv-yak-nevidemna-determinanta-formuvannyayihnih-profesiynih-kompetentsiy [in Ukrainian].

Liubas A. A., orcid.org/0000-0001-6068-6065

\section{FORMATION OF INTERCULTURAL COMPETENCE IN THE PROCESS OF PRACTICAL} TRAINING OF FUTURE SPECIALISTS OF COMBAT AND OPERATIONAL SUPPORT

The article analyzes the effectiveness of the formation of intercultural competence in the process of practical training of future specialists of combat and operational support.

During the training of future specialists of combat and operational support, officers master the skills, abilities, methods and forms of professional activity, namely: practice in the performance of official duties in military units, consolidate theoretical knowledge, develop shelter skills using camouflage properties, barricades, fighting, etc. At command and staff, tactical exercises, cadets practise methods of conducting an operation or combat against the background of a specially created militarypolitical, strategic, operational and combat environment.

It is noted that in the process of internship, future specialists of combat and operational support should develop language skills, such as: multicultural knowledge, knowledge of military-professional values, rules of verbal and nonverbal communicative behavior of servicemen. The purpose of their training is to gain knowledge about the communication styles of American and British servicemen and the use of communication strategies to achieve the goal, the ability to engage in dialogue with representatives of other cultures. Servicemen consolidate skills of tolerant communicative behavior, the ability to control their actions during communication, including the ability to overcome fear, ethnic and cultural stereotypes

It is concluded that during cadets' training and military practice in conditions close to the real ones in order to form intercultural competence, problem-searching teaching methods were found, namely the case method and the educational role-playing game. The use of the case method helps to create conditions for the formation of skills and abilities that are important components of intercultural competence. Educational role-playing game involves modeling situations of professionally oriented communication and aims to train future specialists of combat and operational decision-making.

Key words: intercultural competence, communicative competence, future specialists of combat and operational support, practical training, military-professional training. 